УДК: 615.322:547.466

DOI: $10.15587 / 2519-4852.2018 .146716$

\title{
DETERMINATION OF THE CONTENT OF AMINO ACIDS IN THE ROOTS OF THE SOPHORA FLAVESCENS
}

\author{
(C) G. Shumova, I. Nizhenkovska, I. Vladymyrova
}

Софора жовтіюча (Sophora flavescens L.) родини бобові (Fabaceae) - багаторічна рослина, яка поширена y Росї, в Японії, Кореї, Північно-східному, Північному і Центральному Китаї. Корені иієї рослини містять 1-2\% алкалоїдів (алломатрін, анагірин, ізоматрін, матрін, софокарпін, софорамін, софоранол), тритерпенові сапоніни (соясапонін I), флавоноїди (софорафлавозіди I, II, III, IV, біозанін А, курарідін, курарінон, кушеноли $A, B, C, D, I, K, L, M$; (-) - маакіанін, неокурарінол, норкурарінон) та амінокислоти (пролін, аспарагінова кислота, гліцин, аргенін). Рослинні амінокислоти утворюють велику групу органічних сполук та мають унікальні біологічні та фармакологічні властивості. Тому останнім часом науковці приділяють велику увагу вивченню амінокислотного складу лікарських рослин.

Метою нашої роботи було визначення вмісту амінокислот у софори жовтіючої коренях (roots of Sophora flavescens L.).

Матеріали та методи: Дослідження проводили методом високоефективної рідинної хроматографії (ВЕРХ). Ідентифікацію амінокислот проводили шляхом порівняння часів утримання з сумішшю стандартів амінокислот (Agilent 5061-3334). Вміст зв 'язаних амінокислот визначали шляхом віднімання вмісту вільних амінокислот від їх загального вмісту.

Результати та обговорення: В результаті проведеного дослідження у софори жовтіючої коренях $у$ вільному $і$ зв'язаному стані було виявлено та визначено вміст 15 амінокислот, з яких 6 є незамінними (треонін, валін, метіонін, лейцин, ізолейцин, фенілаланін). У вільному стані у великій кількості накопичується пролін (3,61 мкг/мг) i аспарагінова кислота (0,73 мкг/мг); у зв'язаному стані - глічин (1,25 мкг/мг), аргінін (0,87 мкг/мг), серин (0,84 мкг/мг) та глутамінова кислота $(0,80$ мкг/мг) .

У вільному стані у найменшій кількості накопичується метіонін (0,024 мкг/мг), гліциин (0,040 мкг/мг) та треонін (0,046 мкг/мг); у зв'язаному - пролін (0,079 мкг/мг), аспарагінова кислота (0,229 мкг/мг) та метіонін (0,231 мкг/мг). Така амінокислота, як лізин не була знайдена у софорі жовтіючої коренях.

Висновки: за допомогою метода ВЕРХ нами був визначений вміст 15 вільних та зв'язаних амінокислот y софори жовтіючої коренях, з яких 6 є незамінними. В ряду аналізованих кислот були виявлені моноаміномонокарбонові, моноамінодікарбонові, діаміномонокарбонова, ароматичні та гетероциклічні амінокислоти.3 огляду на те, щзо амінокислоти сприяють швидкому засвоєнню $і$ потенціюванню дії інших біологічно активних речовин (фенольних сполук, полісахаридів, органічних кислот, макро- та мікроелементів), щуо містяться у рослинній сировині, вивчення амінокислот roots of Sophora flavescens L. $\epsilon$ перспективним для використання в офіщійній медицині та дає можливість створення нових препаратів комбінованої дії на основі зазначеного виду лікарської рослинної сировини

Ключові слова: софора жовтіюча, корені, амінокислотний склад, незамінні амінокислоти, високоефективна рідинна хроматографія

\section{Introduction}

The Sophora flavescens L. genus of Fabaceae family is a perennial plant, distributed in Russia in the Far East, in the Primorsky region, in the south-east of the Amur region, in the southwest of the Khabarovsk region. It is also distributed in Asia (Japan, Korea, North-East, North and Central China) and in some European countries [1].

Roots of shrubby Sophora are widely used in Chinese and Tibetan medicine when creating various medicines from many diseases. Nanai, in which this plant is valued above other medicinal herbs, it is called "Godyahkin, Godylahin", in China, where the shrubby Sophora is very popular too, it is called "Ku shen", which in translation means "bitter root". In Ukraine, this plant can be found in the south of the country in the Crimea, it has a whole range of therapeutic properties, namely: general tonic, antipyretic, hemostatic, diuretic, sedative, antitumor, antispasmodic, expressed anti-inflammatory and antimicrobial properties, but is poorly investigated in phytochemical study $[1,2]$.
2. Formulation of the problem in a general way, the relevance of the theme and its connection with important scientific and practical issues

It is known that amino acids are one of the major groups of biologically active substances (BAS) of most plants and are essential for the synthesis of enzymes, alkaloids, vitamins, flavonoids and polyphenolic compounds. They carry out a number of important functions, namely: it is a transport form of nitrogen, precursors of phytohormones, protect against adverse factors, are products of primary metabolism and are found in free form in all plants, and therefore often form part of complex phytopreparations. In this case, amino acids have not only biological activity, but as part of the accompanying substances contribute to improved absorption, prolongation of the therapeutic effect and potentiation of the action of the main plant components [3].

Essential amino acids such as leucine, isoleucine, valine increase human immunity and suppress the growth of malignant neoplasms. Arginine and glutamine have 
antioxidant, hepatoprotective and membrane-stabilizing properties. Alanine and glycine regulate the level of sugar in the blood and are involved in the regeneration of tissues. Serine promotes the accumulation of glycogen in the liver and muscle and affects the exchange of fats. From histidine, a biogenic amine - histamine, which is a local hormone, is formed. Lysine affects the cardiac tone, reduces cholesterol levels in the blood. Methionine prevents deposition of fat in the liver, protects its cells from the effects of toxic substances. Amino acid cysteine is a natural antioxidant [3].

Of particular importance are essential amino acids that are not synthesized in an animal organism. Therefore, the study of the qualitative composition and quantitative content of amino acids in the roots of the shrubby sophora has a scientific and practical significance.

\section{Analysis of recent studies and publications in which a solution of the problem are described and to which the author refers}

Recently, there are many publications devoted to the use of BAS for the correction of various states, metabolic processes, prevention and treatment of various diseases of the human body. Therefore, plants in which the rich composition of the BAS cause more attention from scientists. As noted earlier, the rich chemical composition has Sophora flavescens L. [4, 5]. Scientists D. N. Olennikov and D. V. Sandalov (Institute of General and Experimental Biology, Siberian Branch of the Russian Academy of Sciences) investigated the phenolic compounds of Sophorae flavescens and developed a spectrophotometric method for determining the total content of flavonoid compounds in the underground organs of Sophorae flavescens [6, 7].

Study of the chemical composition of the roots of the shrubby sophora were also studied at the Pyatigorsk Medical and Pharmaceutical Institute (Ph.D., A.B. Samboryadova), the Institute of Plant Protection and the National University of Mongolia (Ganzul G., Byambasuren M., Sukhdolgor J.) [8, 9]. Panthati Murali Krishna, Rao KNV, Sandhya S., David Banji from Nalanda College of Pharmacy (India) investigated alkaloids in Sophora flavescens Ait. method of high performance liquid chromatography [10]. The study of the amino acid composition of the roots of the shrubby sophora was studied by Zhang Jianhua, Wu Yun, Hou Jianhua, Ma Qingzhi (Department of Bioengineering, Inner Mongolia Institute of Agriculture and Animai Husbandry, Huhhot).

In this paper, the content of free amino acids in the roots of Sophora flavescens L was analyzed. The total content of sixteen kinds of free amino acids was $194.52 \mu \mathrm{g} / 100 \mathrm{mg}$; glutamic acid content was highest $(47.68 \mu \mathrm{g} / 100 \mathrm{mg}$ ), and the methionine content was the lowest $(0.20 \mu \mathrm{g} / 100 \mathrm{mg})$ [11].

\section{The field of research considering the general problem, which is described in the article}

Scientists Zhang Jianhua, Wu Yun, Hou Jianhua, Ma Qingzhi studied the content of free amino acids in the roots of Sophora flavescens L. An actual question for us was the analysis of the content of amino acids in both the free and bound state in the studied sample of medicinal plant material. It should be noted that the proteins are complex polymers containing amino acids that come from the digestive tract in the case of digestion of protein nutrients. A special place in metabolic transformations belongs to amino acids. It is the amino acids in the bound state that are the main elements of the construction of proteins and biologically active substances (hormones, vitamins, enzymes) and act as regulators of immune processes.

Sophora flavescens L. is a promising medicinal plant material for use in official medicine and makes it possible to create new drugs of combined action on the basis of the specified type of medicinal plant material and requires a comprehensive phytochemical study. Information on the study of the chemical composition of the Sophora flavescens roots available in Ukraine, in particular studies on the study of the amino acid composition, is very limited.

\section{Formulation of goals (tasks) of article}

The aim of the work was to study the content of amino acids in the shrubby sophora roots (roots of Sophora flavescens $L$.).

6. Presentation of the main research material (methods and objects) with the justification of the results

For the study, we used shrubby sophora roots (supplier - PP "Naidionova", Lviv, the producer China). Quantitative determination of the amino acids of the sophores of the yellowing roots was carried out by the HPLC method. The method is based on the extraction of free amino acids from vegetable raw materials and acid hydrolysis of herbal preparations with the subsequent analysis of hydrolyzates by the HPLC method with percolocal derivatization of 9fluorenylmethoxycarbonyl chloride (FMOC) and ophthalic aldehyde (OPA) followed by detection with a fluorescence detector.

Chromatographic separation was carried out on an Agilent 1200 (Agilent technologies, USA) liquid chromatograph. Zorbax AAA column length $150 \mathrm{~mm}$, internal diameter $4.6 \mathrm{~mm}$, sorbent grain diameter $3 \mu \mathrm{m}$. Mobile phase A - $40 \mathrm{mM}$ Na2HPO4 pH 7.8; B - ACN: $\mathrm{MeOH}$ : water $(45: 45: 10, \mathrm{v} / \mathrm{v} / \mathrm{v})$. Gradient separation mode with a constant flow rate of $1.5 \mathrm{ml} / \mathrm{min}$. Temperature thermostat column $40{ }^{0} \mathrm{C}$. Precolon derivatization was performed in an automatic programmed mode using FMOC reagent (Agilent 50613337) and an OPA reagent (Agilent 5061-3335). Detection of derivatized amino acids was carried out using a fluorescence detector. materials:

Sample preparation and analysis of plant raw

$a$. Free amino acids. The weight of the powdered drug was placed in the vial, $4 \mathrm{ml}$ of aqueous solution of $0.1 \mathrm{~N}$ hydrochloric acid was added and held in an ultrasonic bath at $80{ }^{\circ} \mathrm{C}$ for 3 hours.

$b$. Common amino acids. The weight of the drug was placed in vial, $1 \mathrm{ml}$ of an aqueous solution of $6 \mathrm{~N}$ hydrochloric acid was added and placed in a thermostat at $110^{\circ} \mathrm{C}$. Hydrolysis was carried out for 24 hours. 
An aliquot of centrifuged extract / hydrolyzate is evaporated on a rotary evaporator, rinsed three times with distilled water to remove the hydrochloric acid. Resuspended in a suitable volume of distilled water and filter through membrane filters from regenerated cellulose with pores of $0.2 \mu \mathrm{m}$. The fluorescence derivatives were obtained in an automatic programmable mode before entering the sample into a chromatographic column.
Identification of the amino acids was carried out by comparing the retention times with a mixture of amino acid standards (Agilent 5061-3334). The content of bound amino acids was determined by subtracting the content of free amino acids from their total content [12-14].

Chromatograms obtained as a result of the study of the amino acid composition of the investigated raw material are shown in Fig. 1. Results of determining the quantitative content of amino acids are presented in Table. 1

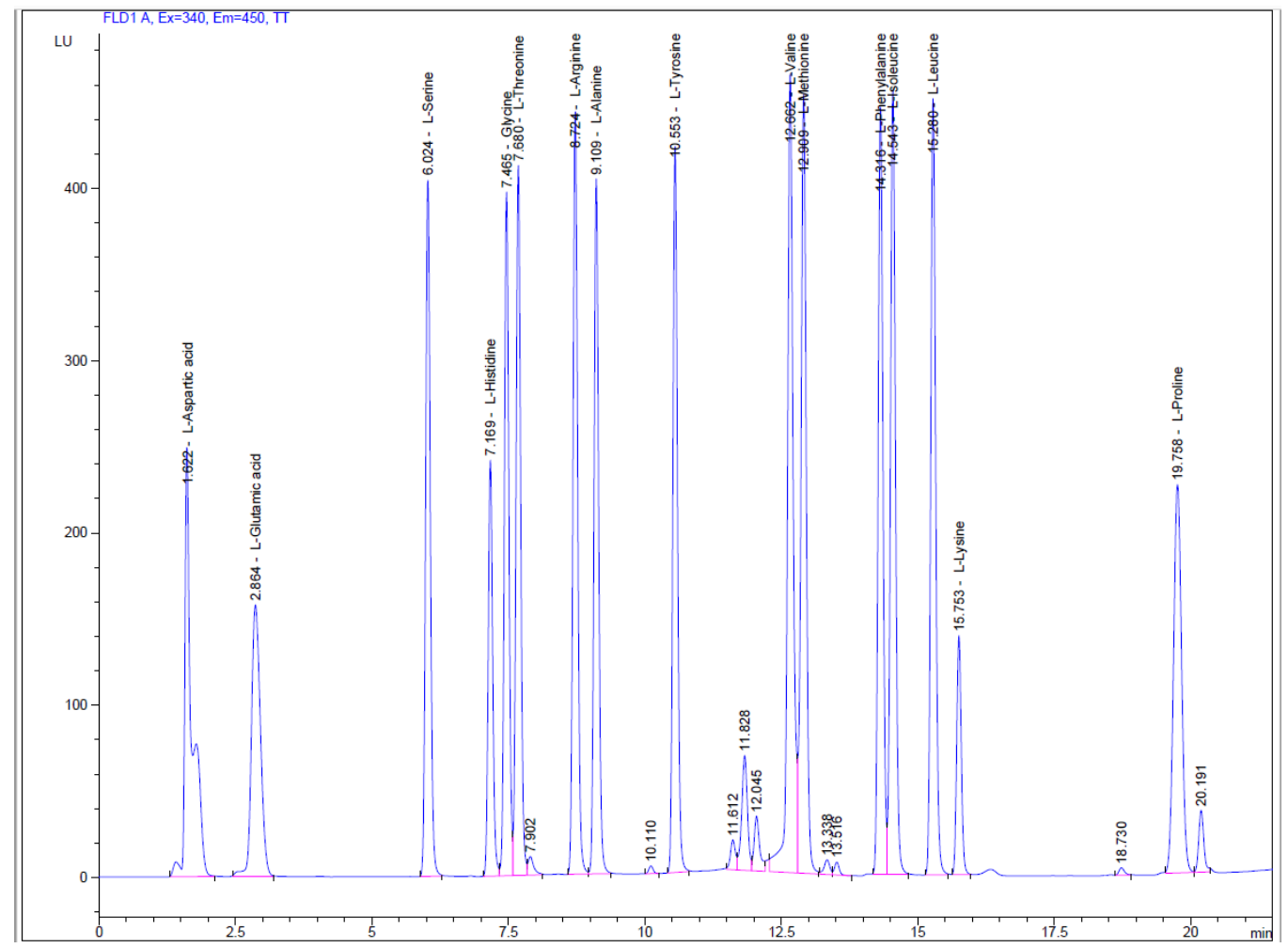

Fig. 1. Chromatogram definition of amino acids in the shrubby Sophora roots

Table 1

Results of determining the content of amino acids in the shrubby Sophora roots

\begin{tabular}{|c|c|l|c|c|c|}
\hline \multirow{2}{*}{ No. } & \multirow{2}{*}{ Retention time, min. } & \multirow{2}{*}{$\begin{array}{c}\text { The name of the amino } \\
\text { acid }\end{array}$} & \multicolumn{3}{|c|}{ Amino acid content, $\mu \mathrm{g} / \mathrm{mg}$} \\
\cline { 3 - 5 } & & L-Aspartic & 0.961 & 0.732 & 0.229 \\
\hline 1. & 1.61 & L-Glutamic & 0.952 & 0.145 & 0.806 \\
\hline 2. & 2.79 & L-Serine & 0.986 & 0.139 & 0.846 \\
\hline 3. & 5.98 & L-Histidine & 0.708 & 0.066 & 0.642 \\
\hline 4. & 7.12 & Glycine & 1.292 & 0.040 & 1.252 \\
\hline 5. & 7.41 & L-Threonine & 0.472 & 0.046 & 0.426 \\
\hline 6. & 7.63 & L-Arginine & 1.034 & 0.163 & 0.871 \\
\hline 7. & 8.70 & L-Alanine & 0.583 & 0.132 & 0.451 \\
\hline 8. & 9.049 & L-Tyrosine & 0.506 & 0.098 & 0.409 \\
\hline 9. & 10.49 & L-Valine & 0.575 & 0.149 & 0.426 \\
\hline 10. & 12.60 & L-Methionine & 0.687 & 0.024 & 0.231 \\
\hline 11. & 12.81 & L-Phenylalanin & 0.407 & 0.093 & 0.625 \\
\hline 12. & 14.23 & L-Isoleucine & 0.807 & 0.049 & 0.314 \\
\hline 13. & 14.44 & L-Leucine & 3.689 & 3.611 & 0.758 \\
\hline 14. & 15.18 & L-Proline & & 0.079 \\
\hline 15. & 19.65 & &
\end{tabular}

As a result of a free and bound chromatographic study, the content of 15 amino acids, of which 6 are irreplaceable (threonine, valine, methionine, leucine, isoleucine, phenylalanine) are detected and determined in the free and bound
state.Among the identified amino acids, most (11 compounds) belong to the aliphatic group; there is also the presence of 2 aromatic and 2 heterocyclic amino acids, which is consistent with the literature data on the content of amino acids in plants $[3,15]$. 
Aliphatic acids are represented by 8 monoaminocarboxylic acids (glycine, alanine, valine, isoleucine, leucine), including containing threonine, serine and sulfur-containing (methionine) compounds. Monoaminodicarboxylic acids are represented by aspartic and glutamic acid, diaminomonocarboxylic acid by arginine. Of the aromatic amino acids in the shrubby sophora roots, tyrosine and phenylalanine have been detected. As representers of heterocyclic acids, there are proline and histidine.

During the study, it was found that in the free state in large quantities, proline $(3.61 \mu \mathrm{g} / \mathrm{mg})$ and aspartic acid $(0.73 \mu \mathrm{g} / \mathrm{mg})$ accumulate; in the bound state - glycine $(1.25 \mu \mathrm{g} / \mathrm{mg})$, arginine $(0.87 \mu \mathrm{g} / \mathrm{mg})$, serine $(0.84 \mu \mathrm{g} / \mathrm{mg})$ and glutamic acid $(0.80 \mu \mathrm{g} / \mathrm{mg})$.

In the free state, methionine $(0.024 \mu \mathrm{g} / \mathrm{mg})$, glycine $(0.040 \mu \mathrm{g} / \mathrm{mg})$ and threonine $(0.046 \mu \mathrm{g} / \mathrm{mg})$ accumulate in the smallest amount; in the bound state proline $(0.079 \mu \mathrm{g} / \mathrm{mg})$, aspartic acid $(0.229 \mu \mathrm{g} / \mathrm{mg})$ and methionine $(0.231 \mu \mathrm{g} / \mathrm{mg})$.

Such an amino acid as lysine was not defined in the shrubby sophora roots.
7. Conclusions from the conducted research and prospects for further development of this field

1. Thus, by the HPLC method, the content of 15 amino acids, of which 6 are irreplaceable (threonine, valine, methionine, leucine, isoleucine, phenylalanine) are detected and determined in the shrubby sophora roots in a free and bound state. In the series of analyzed acids, monoaminomonocarbonic, monoaminoidicarbonic, diaminomonocarboxylic, aromatic and heterocyclic amino acids were detected.In the sophora gravelescens roots, proline $(3.61 \%)$ is accumulated in the free state of the identified amino acids and in the bound state it is glycine $(1.25 \%)$.

2. In the free state, methionine $(0.024 \%)$ and glycine $(0.040 \%)$ accumulate in the smallest amount; in the bound state - proline $(0,079 \%)$, aspartic acid $(0,229 \%)$ and methionine $(0,231 \%)$. The amino acid of lysine was not defined in the sophora gravelescens roots. The obtained data contribute to the expansion of information on the chemical composition of medicinal plant material and will be used in future for specified substance-markers.

\section{References}

1. Perspektyvy zastosuvannia sofory zhovtiuchoi u medytsyni ta farmatsiyi / Shumova H. S. et. al. // Materialy naukovopraktychnoi konferentsiyi z mizhnarodnoiu uchastiu «Aktualni pytannia narodnoi i netradytsiinoi medytsyny v kompleksniyi terapiyi». Kyiv, 2018.

2. Sandanov D. V., Shobolova A. B. Farmakologicheskie svoystva Sophora flavescens Soland. i ee primenenie v narodnoy i tradicionnoy medicine // Byulleten' VSNC SO RAMN. 2011. Issue 1 (77). P. 268-270. 2014. $228 \mathrm{p}$

3. Aminokisloty glazami himikov, farmacevtov, biologov. Vol. 1 / Syrovaya A. O. et. al. Kharkiv: Shchedra sadiba plyus,

4. Sedative Effect of Sophora flavescens and Matrine / Lee H. et. al. // Biomolecules \& Therapeutics. 2017. Vol. 25 , Issue 4. P. 390-395. doi: https://doi.org/10.4062/biomolther.2016.156

5. Nagai N. Study on Sophora flavescens // Yakugaku Zasshi. 1889. Vol. 84. P. 54-87.

6. Olennikov D. N., Sandalov D. V. Fenol'nye soedineniya Sophorae flavescens (Fabaceae). Komponentnyy sostav i biologicheskaya aktivnost' (obzor literatury) // Rastitel'nye resursy. 2010. Vol. 46, Issue 2. P. 126-159.

7. Olennikov D. N., Sandalov D. V. Spektrofotometricheskiy metod opredeleniya summarnogo soderzhaniya flavonoidnyh soedineniy v podzemnyh organah Sophorae flavescens (Fabaceae) // Rastitel'nye resursy. 2010. Vol. 46, Issue 3. P. 131-138.

8. Samoryadova A. B. Ispol'zovanie fiziko-himicheskih metodov dlya opredeleniya soderzhaniya flavonoidov v sofore zhelteyushchey (Sophora flavescens) kornyah // Farmaciya i farmakologiya. 2015. Issue 1 (8). P. 43-45.

9. Ganzul G., Byambasuren M., Sukhdolgor J. A study of biochemical composition on Sophora flavescens Soland // International journal of research - Granthaalayah. 2018. Vol. 6, Issue 1. P. 480-483. doi: http://doi.org/10.5281/zenodo.1172284

10. Characterization of alkaloids in Sophora flavescens Ait. by high-performance liquid chromatography-electrospray ionization tandem mass spectrometry / Liu G. et. al. // Journal of Pharmaceutical and Biomedical Analysis. 2011. Vol. 54, Issue 5. P. 1065-1072. doi: https://doi.org/10.1016/j.jpba.2010.12.024

11. Jianhua Z. Determination of the Contents of Free Amino Acids in Sophora alopecuroides Linn. URL: http://en.cnki. com.cn/Article_en/CJFDTOTAL-AJSH704.010.htm

12. Rapid, Accurate, Sensitive, and Reproducible HPLC Analysis of Amino Acids. Amino Acid Analysis Using Zorbax Eclipse-AAA Columns and the Agilent 1100 HPLC / Henderson J. W. et. al. // Agilent Technical Note. 1999. P. 5980-1193E. URL: https://www.agilent.com/cs/library/chromatograms/59801193.pdf

13. Jámbor A., Molnár-Perl I. Quantitation of amino acids in plasma by high performance liquid chromatography: Simultaneous deproteinization and derivatization with 9-fluorenylmethyloxycarbonyl chloride // Journal of Chromatography A. 2009. Vol. 1216, Issue 34. P. 6218-6223. doi: https://doi.org/10.1016/j.chroma.2009.06.083

14. Jámbor A., Molnár-Perl I. Amino acid analysis by high-performance liquid chromatography after derivatization with 9 fluorenylmethyloxycarbonyl chloride // Journal of Chromatography A. 2009. Vol. 1216, Issue 15. P. 3064-3077. doi: https://doi.org/ 10.1016/j.chroma.2009.01.068

15. Wu G. Amino acids: metabolism, functions, and nutrition // Amino Acids. 2009. Vol. 37, Issue 1. P. 1-17. doi: https://doi.org/10.1007/s00726-009-0269-0

Ganna Shumova, PhD, Assistant, Department of Pharmaceutical, Biological and Toxicological Chemistry, Bogomolets National Medical University, T. Shevchenka blvd., 13, Kyiv, Ukraine, 01601

E-mail: shumova_ganna@i.ua 
Irina Nizhenkovska, Doctor of Pharmaceutical Sciences, Professor, Department of Pharmaceutical, Biological and Toxicological Chemistry, Bogomolets National Medical University

T. Shevchenka blvd., 13, Kyiv, Ukraine, 01601

E-mail: fbth@nmu.ua

Inna Vladymyrova, Doctor of Pharmaceutical Sciences, Associate Professor, Department of Pharmacognosy, National University of Pharmacy, Pushkinska str., 53, Kharkiv, Ukraine, 61002

E-mail: inna.vladimirova2015@gmail.com

\author{
УДК:615.212.3./4'791/.792
}

DOI: $10.15587 / 2519-4852.2018 .146847$

\title{
ANTIPYRETIC ACTIVITY OF THE NEW 2-(((3-MERCAPTO-5-METHYL-4H-1,2,4- TRIAZOL-4-YL)IMINO)METHYL)-5-R-BENZOATES
}

\section{(C) T. Kravchenko, O. Panasenko, Ye. Knysh}

Підвищення температури тіла є необхідною захисною реакцією організму, щзо активує імунну систему та підсилюе фагоцитоз, ие призводить до пригнічення розмноження вірусів та бактерій. Жарознижувальна дія, що супроводжується збільшенням тепловіддачі через розширення судин шкіри та посилене потовиділення, пов'язана значною мірою із заспокійливим впливом на збудливість теплорегулюючих иеентрів проміжного мозку, яка змінюється під впливом патологічного прочесу.

Підвищення температури вище за $39{ }^{\circ} \mathrm{C}$ є небезпечним фактором для дорослих і дітей різних вікових категорій.

Незважаючи на високу ефективність анальгетиків, їх використання не завжди безпечне. Застосування аспірину підвищує ризик розвитку запальних змін з боку шлунково-кишкового тракту, підвищує ламкість судин, порушує згортання крові.Пошук нових високоефективних лікарських засобів із жарознижувальною дією є актуальною проблемою сьогодення.

Метою нашої роботи є фармакологічний скринінг антипіретиків серед вперше синтезованих 2-(((3меркапто-5-метил-4H-1,2,4-тріазол-4-іл)іміно)метил)-5-R-бензоатів.

Матеріали та методи дослідження. Об'єктами дослідження стали нові 2-(((3-меркапто-5-метил-4H1,2,4-тріазол-4-іл)-іміно)-метил)-5-R-бензоати.

Експериментальну лихоманку проводили на білих нелінійних шурах шляхом введення 2,4-динітрофенолу (2,4-ДНФ) (роз'єднувач окисного фосфорилювання) в дозі 20 мг/кг. В якості референс-препарату використовували ацетилсаліцилову кислоту в дозі 100 мг/кг.

Досліджувані речовини вводили через пів години $\left(T_{0,5}\right)$ після введення 2,4-ДНФ, фіксували ректальну температуру тіла протягом 1 години $\left(T_{1}\right)$. Початкову ректальну температуру $\left(T_{0}\right)$ реєстрували до внутрішньочеревної ін'єкиї̈ 2,4-ДНФ. В якості препарату порівняння використовували ацетилсаліцилову кислоту в дозі $100 \mathrm{мг/кг.}$

Результати дослідження та обговорення. За даними серії досліджень було встановлено, щзо внутрішньочеревинне введення 2,4-ДНФ через 30 хвилин викликало підвищення температури тіла щурів $(n=133)$ в середньому з $37,36^{\circ} \mathrm{C}$ до $38,37^{\circ} \mathrm{C}\left({ }_{4} T=0,88^{\circ} \mathrm{C}\right)$.

Щодо референтного препарату ацетилсаліџилової кислоти, встановлено, щзо при ї̈ застосуванні за модельованої патології значення температури тіла шурів знижувались на $3 \%\left({ }_{4} T=-1,2{ }^{\circ} \mathrm{C}, p \leq 0,05\right)$ по відношенню до контрольної групи.

Згідно отриманим результатам в ході експерименту було виявлено сполуки, які за своїм ефектом перевищували референс-препарат. Так, сполуки IV, V та VIII знижували показники температури тіла щурів більи ніж на 0,39\%.

Серед досліджуваних речовин привертають на себе увагу сполуки IV ma $V$, які знижували показники температури тіла щурів в інтервалі 4,66-4,95 \% і при цььому знижували температуру від 1,19 до 2,10 ${ }^{\circ} \mathrm{C}$.

Висновки. Синтезовано нові 2-(((3-меркапто-5-метил-4H-1,2,4-тріазол-4-іл)іміно)метил)-5-R-бензоати. Найбільш активною серед досліджуваних сполук є амоній 2-(((3-меркапто-5-метил-4H-1,2,4-тріазол-4іл)-іміно)-метил)бензоат. Перехід до солей із неорганічними катіонами призводить до втрати активності. Так, заміна катіонів на піперидиній дещуо підвищує показники активності, проте сполука поступається за силою ефекту референс-препарату

Ключові слова: похідні 1,2,4-тріазолу, органічний синтез, біологічна активність, жарознижуюча дія, антипіретики, гіпертермія

\section{Introduction}

Thermoregulation of the body relies on the balance of physiological processes of thermogenesis and thermolysis, which are controlled by neural and hormonal mechanisms. Antipyretic activity, which involves the increase of thermolysis through angiectasis 